\title{
Review of Teaching Adult Immigrants with Limited Formal Education: Theory, Research and Practice
}

\author{
Aydın Yücesan Durgunoğlu, University of Minnesota Duluth
}

Around the globe, there are almost 80 million people who have been forcibly displaced, which is the highest level the world has ever experienced (United Nations Refugee Agency, n.d.). When these adults arrive to highly literate societies, they are required to rapidly develop both oral and written language skills in order to survive, gain employment, become citizens and help their children thrive. It is a tall order for individuals who have left their homes under horrible circumstances and may have had their education interrupted because of war, conflict, economic struggles, cultural constraints (Durgunoğlu \& Nimer, 2020). Some of these immigrants are developing literacy skills for the first time and in a new language. This book focuses on this oftenoverlooked population, adult immigrants with limited formal education, and it is a timely addition to the field.
Except for the last chapter, this is not a book on effective practices in the classrooms, rather the chapters primarily provide an overview of linguistic and sociocultural concepts that are important for teachers to know. This is praiseworthy, because as Fillmore and Snow (2000) recommended two decades ago, teachers should learn more about language in order to be effective communicators, educators, evaluators. This book introduces the multifaceted and complex constructs that constitute what we call "language." In each chapter, contributors give an overview of one aspect of literacy development, and then apply those findings to this specific adult population. This book is a good resource in education programs preparing adult educators. It can also benefit teachers who work with adults developing literacy for the first time in a new language, irrespective of the language. 
In their overview in Chapter 1, Peyton and YoungScholten explain that their book emerged from a project that developed six modules to train teachers around the world who were working with adults with low or limited literacy. In countries that have welcomed immigrants, adult educators face similar challenges despite teaching different languages. In Chapters 2-6, different authors discuss the cognitive, sociocultural, and educational aspects of the challenge of both learning a new language and becoming literate in it.

In Chapter 2, "Language and Literacy in Social Context," Suni and Tammelin-Laine describe the situation in Finland. Although Finland is one of the top-performing countries on global literacy and numeracy tests such as PIAAC or PISA, there is a serious gap between migrant versus non-migrant learners. This chapter emphasizes that literacy is culturally mediated, consequently teachers and learners may have different perspectives on the value and use of literacy. The concept of "affordance" is highlighted, describing how learners perceive different learning opportunities in the environment and select to focus on those they determine to be worthwhile or needed. The authors emphasize the usefulness of collaborative learning, scaffolding and support both inside and outside of the classroom.

Chapters 3, 4 and 5 discuss the cognitive foundations of literacy development. In Chapter 3, using a psycholinguistic perspective, Sosiński provides an overview of both bottom-up and top-down processes of literacy and provides examples of literacy activities in Spanish. Next, in Chapter 4, Rohde et al. offer a thorough overview of the complex clusters of information (semantic, syntactic, orthographic, morphological, pragmatic, relational) that characterize vocabulary knowledge and the challenges for second language (L2) learners. Because of limited research on vocabulary development of adults with low literacy, the authors draw heavily from research on the vocabulary development of children in their early years, when they are not yet literate. The authors also offer practical strategies for teaching vocabulary.

In Chapter 5, Young-Scholten and Naeb cover the acquisition and assessment of morphosyntax knowledge, which plays an important role in reading comprehension. This chapter reviews research based on the target group of interest, adult L2 learners, but of course, the educational backgrounds of this population are varied, and most recent research is conducted with college and high school students learning a foreign language, after they are fully literate in their first language (L1). To their credit, the authors of this chapter refer to research from the 1970s with migrant adults. One strong claim of the chapter is that an adult's acquisition of morphosyntax in an L2 follows a developmental pattern that is largely independent of the learner's L1, age at exposure to this new language, educational background and whether the learning occurs inside or outside the classroom. This conclusion assumes common stages in morphosyntactic development for L1 and L2 speakers of a language and has strong implications for teaching morphosyntactic constructs in a sequential order.

Chapter 6 by Haznedar provides an extensive overview of bilingual children and their education. Although this chapter is not directly related to the education of adult immigrants with limited schooling, teachers may use this particular chapter to discuss with adult immigrants their children's bilingualism and ways to maintain their heritage language.

The last chapter by Faux and Watson is the one that is most directly related to instruction. The 
authors list topics to consider when working with adults developing literacy skills for the first time and in an unfamiliar language. These topics include: preparing relevant, socioculturallysensitive materials, getting to know the learners and their existing literacy experiences, acknowledging the emotional aspect of instruction and creating a safe space, and finally, considering the kinds of learning that takes place outside of the classroom. This chapter also addresses the challenge of how to teach a class that includes learners with varying levels of literacy and L2 proficiency.

One concern that I have is that, for a book that covers the literacy development of adults, across the chapters there is a very strong emphasis on child oral and written language development. Drawing too many parallels with child development may lead practitioners to overlook what adults already know and bring from their L1s. Despite low levels of literacy (hence the parallel with children beginning to read), adults have already well-developed oral language skills. They also possess life experiences, problem-solving skills, and social networks. Some immigrants are likely to speak two or more languages and thus have metalinguistic awareness about how languages represent concepts. If classroom teachers use child research findings as a direct guide to understand L2 development in adults, they may unintentionally discount adults' L1 knowledge, experiences, and most of all the adult mind. After all, as Young-Scholten \& Naeb state in Chapter 5, "adults are more cognitively sophisticated than children."

Overall, this volume is a good resource for educators to understand the foundations of oral and written language development. Armed with this knowledge, teachers can then develop effective classroom practices to address the needs of this understudied, and yet rapidly growing group of adult learners. 


\section{References}

Durgunoğlu, A.Y. \& Nimer, M. (2020) A holistic approach to new language literacy development of refugee women: The case of Syrians in Turkey. In A.M. Krulatz, G. Neokleous \& R. Farrelly (Eds). Handbook of research on cultivating literacy in diverse and multilingual classrooms. IGI Global. https://doi.org/10.4018/978-17998-2722-1
Fillmore, L. W., \& Snow, C. (2000). What teachers need to know about language. In C. T. Adger, C. E. Snow, \& D. Christian (Eds.), What teachers need to know about language (pp. 7-53). Delta Systems/Center for Applied Linguistics .

United Nations Refugee Agency. (n.d.). Figures at a glance. https://www.unhcr.org/en-us/figures-at-a-glance.html 